13 Katzenstein D, Rickerson V, Braude A. New concepts of amebic liver abscess derived from hepatic imaging, serodiagnosis, and hepatic enzymes in 67 consecutive cases in San Diego. Medicine (Baltimore) 1982; 61: 237-46.

14 Irusen EM, Jackson TFHG, Simjee AE. Asymptomatic intestinal colonization by pathogenic Entamoeba histolytica in amebic liver abscess: prevalence, response to therapy and pathogenic potential. Clin Infect Dis 1992; 14: 889-93.

15 Ravdin JI. Intestinal disease caused by Entamoeba histolytica. In: Ravdin JI ed. Amebiasis: human infection by Entamoeba histolytica. New York: Churchill Livingstone, 1988: 495-510.

16 Petri WA, Smith RD, Schlesinger PH, Ravdin JI. Isolation of the galactosebinding lectin which mediates the in vitro adherence of Entamoeba binding lectin which mediates the in
histolytica. $\mathcal{F}$ Clin Invest 1987; 80: 1238-44.

17 Petri WA Jr, Chapman MD, Snodgrass T, Mann BJ, Broman J, Ravdin JI Subunit structure of the galactose and N-acetyl-D-galactosamine-inhibitable
adherence lectin of Entamoeba histolytica. $f$ Biol Chem 1989; 264: adherence

18 Mann BJ, Chung CY, Dodson JM, et al. Neutralizing monoclonal antibody epitopes of the Entamoeba histolytica galactose adhesin map to the cysteinerich extracellular domain of the 170-kilodalton heavy subunit. Infect Immun 1993; 61: 1772-8.
19 Tannich E, Ebert F, Horstmann RD. Primary structure of the 170-kDa surface lectin of pathogenic Entamoeba histolytica. Proc Natl Acad Sci 1991; 88: 1849-53.

20 Abd-Alla M, El-Hawey AM, Ravdin JI. Use of ELISA to detect anti-adherence protein antibodies in sera from patients with invasive amebiasis in Cairo, Egypt. Am 7 Trop Med Hyg 1992; 47: 800-4.

21 Grundy MS. Preliminary observations using a multi-layer ELISA method for the detection of Entamoeba histolytica trophozoite antigens in stool samples. Trans $R$ Soc Trop Med Hyg 1982; 76: 396-400.

22 Merino E, Glender W, del Muro R, Ortiz-Ortiz L. Evaluation of the ELISA test for detection of Entamoeba histolytica in feces. F Clin Lab Anal 1990; 4: $39-42$.

23 Gonzalez-Ruiz A, Haque R, Rehman T, et al. A monoclonal antibody for distinction of invasive and noninvasive clinical isolates of Entamoeba distinction of invasive and noninvasive clinica

24 Acuna-Soto R, Samuelson J, De Girolami P, et al. Application of the polymerase chain reaction to the epidemiology of pathogenic and nonpathogenic Entamoeba histolytica. Am f Trop Med Hyg 1993; 48: 58-70.

25 Haque R, Kress K, Wood S, et al. Diagnosis of pathogenic Entamoeba histolytica infection using stool ELISA based on monoclonal antibodies to the galactose-specific adhesin. $\mathcal{F}$ Infec Dis 1993; 167: 247-9.

\title{
Editorial
}

\section{Gut index change}

There will be a change in the indexing of the journal starting with the 1994 index. Papers and proceedings will be indexed using a keyword system. Authors will be asked to select up to five keywords for each paper at manuscript stage, which will then be used to compile the annual index. A keyword is a word (or phrase) that will identify the subject matter of a written paper or proceeding in an index. The index will be published, as usual in the December issue. The format will be different, with the title of the paper repeated after each keyword entry. The author index will no longer include the title of the paper and will become a list of authors only.

Authors should scan papers for headings that may not be in the title, to use British approved names rather than pharmaceutical names for drugs, and to avoid general terms such as clinical, complications, adverse effects, and patient. As the subject of the journal is the 'digestive system' this should not be used as a heading. In general, it is preferable not to split accepted concepts. For instance, upper gastrointestinal tract is preferable as a keyword, rather than tract, upper gastrointestinal.

Some shortened forms can be accepted such as DNA, AIDS, HIV, and cAMP, which are universally known, but mostly the full form should be used as the keyword. Alpha fetoprotein, alpha and beta receptor blockades for example are usually submitted in full. Greek letters are not generally used in alphabetisation. Other examples include the use of oesophagus rather the oesophageal, but growth factors should be placed under the specific type, for example, epidermal, fibroblast. There will be no cross references in the keyword index. 